\title{
Microbial additives affect silage quality and ruminal dry matter degradability of avocado (Persia Americana) pulp silage
}

\author{
B.D. Nkosi ${ }^{1,2 \#}$, R. Meeske ${ }^{2}$, M.C. Muya ${ }^{1}$, T. Langa ${ }^{1}$, R.S. Thomas ${ }^{1}$, I.M.M. Malebana ${ }^{1}$, M.D. \\ Motiang ${ }^{1}$, \& J.A. van Niekerk ${ }^{2}$ \\ ${ }^{1}$ Division for Animal Nutrition: Animal Production Institute, P/Bag $\times 2$, Irene, 0062, South Africa \\ ${ }^{2}$ Centre for Sustainable Agriculture, University of the Free State, P.O. Box 339, Bloemfontein, 9300, South Africa \\ ${ }^{3}$ Animal Sciences, Department of Agriculture Western Cape, Outeniqua Research Farm, P.O. Box 249, George, 6530, \\ South Africa
}

(Received 23 April 2019; Accepted 22 November 2019; First published online 1 January 2020)

Copyright resides with the authors in terms of the Creative Commons Attribution 4.0 South African Licence.
See: http://creativecommons.org/licenses/by/4.0/za
Condition of use: The user may copy, distribute, transmit and adapt the work, but must recognise the authors and the South African
Journal of Animal Science.

\begin{abstract}
This study evaluated effects of microbial inoculation on fermentation, aerobic stability and ruminal dry matter (DM) degradation of silage produced from Avocado (Persia Americana) pulp (AP). The AP, $800 \mathrm{~g} / \mathrm{kg}$ fresh matter (FM) was mixed with $150 \mathrm{~g}$ grape pumice (GP)/kg FM and $50 \mathrm{~g}$ sugarcane molasses/kg FM. The mixture was treated with 1) no inoculant (control), 2) Emsilage inoculant (EMS), and 3) Sil-All 4x4 W.S. inoculant (SIL). Materials were ensiled in $1.5 \mathrm{~L}$ anaerobic jars for 90 days. Triplicate samples were collected on days $0,3,7,10$, and 90 for determination of fermentation, nutritive value and aerobic stability. In situ DM degradability was determined using 3 rumen cannulated Holstein cows. Microbial inoculation to AP silage increased lactic acid bacteria population, which subsequently increased residual fermentation substrate and lactic acid content. Terminal $\mathrm{pH}$ and volatile fatty acids of the silage were not affected by inoculation. Inoculated silage had less fibre and reduced aerobic stability compared to the control. The AP and its mixture had higher DM soluble fractions compared to the GP which had a higher degradation rate. Potential degradable fraction and extent of degradation were similar for each treatment. The EMS treatment had higher soluble fractions and lower degradation rate than other treatments. Inoculation with SIL improved degradation of the silage compared to other treatments. Thus, microbial inoculation qualifies the AP silage as a potential feed for ruminants.
\end{abstract}

Keywords: feed, grape pomace, inoculant, oil cake, organic acid

${ }^{\#}$ Corresponding author: dnkosi@arc.agric.za

\section{Introduction}

The greatest constraint to livestock productivity for resource-poor livestock farmers in South Africa is the shortage of feeds and forages, which can be remedied through better utilization of locally available resources, such as agro-industrial by-products. These resources are available in substantial quantities from fruit/vegetable processing and oil production industry. They often contain valuable nutrients that can benefit animal production (De Evan et al., 2019). However, one of the limitations of using high moisture by-products in livestock production is their low DM (less than $250 \mathrm{~g} \mathrm{DM} / \mathrm{kg}$ ) content.

South Africa produces on average about 90000 tonnes of avocados (Persea Americana) per year (SAAGA, 2019) which are exported or consumed locally. Avocado pulp (AP) is a by-product from the production of oil and is unsuitable for human consumption (Skenjana et al., 2006). This by-product contains less than $200 \mathrm{~g} \mathrm{DM} / \mathrm{kg}, 20 \mathrm{MJ}$ of gross energy $/ \mathrm{kg} \mathrm{DM}, 81.4 \mathrm{~g}$ crude protein $/ \mathrm{kg} \mathrm{DM}$ and $119 \mathrm{~g}$ ether extract $/ \mathrm{kg}$ DM (Nkosi et al., 2018). Skenjana et al. (2006) reported that this by-product has an in vitro organic matter digestibility of $54 \%$ and a relatively high ruminal DM degradation of $67 \%$. The availability of AP is seasonal and its use in animal feeding throughout the year requires ensiling and storage. The challenges for ensiling AP include is its low content of DM (less than $200 \mathrm{~g} \mathrm{DM} / \mathrm{kg}$ ) and high content of ether extract (182 $\mathrm{g}$ ether extract (EE)/kg DM) (Eliyahu et al., 2015). In a previous study by Eliyahu et al. (2015), AP was ensiled without the use of silage inoculants and additives (e.g. absorbents) and this resulted in poor-quality silage. Another by-product is grape pomace (GP) from the wine production industry. This GP can be used to 
improve silage-making characteristics of high moisture forages by increasing the DM matter content and enriching the silage with nutrients that remained following wine production (Dos Santos Belem et al., 2016).

Silage making can utilize inoculants and other additives to improve the fermentation process and its aerobic stability. The use of urea and formic acid during the ensiling of oil cake (e.g. olive cake) has been reported to improve crude protein (CP) degradation kinetics ( $a$ and $b$ ) and effective degradability of olive cake silage (Rowghani et al., 2008). However, using chemical additives, such as formic acid, during ensiling of forages also has limitations. They can be dangerous when not handled properly and may be corrosive to equipment. Consequently, microbial silage inoculants, such as lactic acid bacteria (LAB), are used to improve silage fermentation and prevent spoilage through increased organic acid production, mainly lactic acid (LA) and acetic acid. While plants contain native $L A B$, the number of viable $L A B$ in forage can be insufficient and delay the decline in $\mathrm{pH}$ during ensiling. Inoculating forages with $\mathrm{LAB}$ at ensiling ensures the presence of sufficient $L A B$ to cause a rapid reduction in $\mathrm{pH}$, which may contribute to the elimination of undesirable fermentation and reduce proteolysis (Muck, 2010). The epiphytic populations of LAB in the forage influence the effect of a given inoculant on the ensiling process. This is may explain the inconsistent results with the use of LAB inoculants during ensiling (Muck et al., 2018). Similarly, animal performance (for example, milk production, DM intake) and nutrient degradation have varied when feeding silages treated with LAB. To our knowledge, no published information is available on the feasibility of making silage from AP mixed with GP. Therefore, the objective of this study was to evaluate the effects of microbial inoculation of an AP-GP mixture at ensiling on its fermentation characteristics, nutritive value, aerobic stability and ruminal DM degradation.

\section{Materials and methods}

For this study, AP was collected from Westfalia, Limpopo Province and brought to ARC-Irene, Pretoria, South Africa for nutrient analyses and silage production. An amount of $800 \mathrm{~g} \mathrm{AP} / \mathrm{kg}$ FM was mixed with $150 \mathrm{~g} \mathrm{GP} / \mathrm{kg}$ FM and $50 \mathrm{~g}$ sugarcane molasses/kg FM. Thirty $\mathrm{kg}$ of mixture was produced for each treatment and mixed on a plastic sheet prior to ensiling. The mixtures were treated with: 1) no additive (control), 2) Emsilage (EMS) inoculant (Proiokashi PTY LTD, La Source, Devon Valley, Stellenbosch, 7600, South Africa), and 3) Sil-All 4x4 W.S. (SIL) inoculant (Danstar Ferment A.G., CH-6301 Zug, Switzerland). The EMS was prepared in accordance with the manufacturer's prescription by mixing $4.8 \mathrm{ml}$ EMS with 115.2 $\mathrm{ml}$ water and treated $30 \mathrm{~kg}$ of AP mixture. The SIL was prepared by mixing $3 \mathrm{~g}$ inoculant with $120 \mathrm{ml}$ water and treated $30 \mathrm{~kg} \mathrm{AP}$ mixture. This was done to meet a targeted inoculation rate of $3.5 \times 10^{5}$ colony forming units (CFU)/g of fresh forage. To ensure the same amount of moisture as in the treated forage, the control (30 kg fresh forage) was sprayed with $120 \mathrm{~mL}$ water just prior to compaction in silos. In order to ensure that the required application of inoculant per fresh forage was obtained before ensiling, the suspensions were plated immediately on de Man, Rogosa and Sharpe agar (Oxoid CM0361, Unipath, Basingstoke, UK) and analysed for LAB populations following the International Dairy Federation (IDF) Standard (2004) procedure.

The silage material was thoroughly mixed before being ensiled into $1.5 \mathrm{~L}$ anaerobic jars (J. Weck, GmBHu. Co., Wehr-Oflingen, Germany). Representative samples of AP mixtures were collected after application of inoculants for chemical analyses. Each jar was filled with approximately $850 \mathrm{~g}$ (wet weight) chopped forage without headspace, and a packing density of $567 \mathrm{~kg} \mathrm{FM} / \mathrm{m}^{3}$ was obtained. A total of 36 jars were filled (12 jars per treatment), and they were stored at a temperature of $24^{\circ} \mathrm{C}$ to $28{ }^{\circ} \mathrm{C}$ to follow fermentation dynamics. Triplicate samples per treatment were collected at day 0 (pre-ensiled materials) and three jars per treatment were then opened on $\mathrm{d} 3,7,10$, and 90 post ensiling to determine $\mathrm{pH}$. In addition, samples of day 90 were analysed for the nutritive values and fermentation characteristics.

Samples of d 90 were subjected to an aerobic stability test in which a $500 \mathrm{~g}$ sample from each jar was packed loosely in an open plastic jar, covered with two layers of cheesecloth and kept at $28{ }^{\circ} \mathrm{C}$. Thermocouples ( $T$-type copper constantan, 20-gauge wire) were placed in the geometric centre of the silage mass in each jar and in the room where the jars were stored to record temperature. Room temperature and the temperature in each jar were simultaneously recorded at one-hour intervals using a CR7X data logger (Campbell Scientific, Logan, Utah) for $7 \mathrm{~d}$. Carbon dioxide $\left(\mathrm{CO}_{2}\right)$ production (Ashbell, et al., 1991), $\mathrm{pH}$ and yeasts and moulds were determined after the seven-day exposure following the IDF procedure (2004). The aerobic stability was denoted as the time (h) that the silage remained stable before rising to a temperature that was at least $2{ }^{\circ} \mathrm{C}$ above the ambient.

Three rumen cannulated mid-lactation (180 \pm 5 days in milk) Holstein cows with an average body weight of $667 \pm 43 \mathrm{~kg}$ were used to determine the in-situ rumen DM degradation. Cows were milked twice daily at 12-h intervals and were offered a 40:60 forage to concentrate ratio total mixed ration formulated to meet their nutrient requirements (NRC, 2001) ad libitum at 8:00 in the morning. Animals were cared for according to the guidelines for the Care and Use of Animals in Federation of Animal Science Societies (2010) and the Animal Ethics Committee of the South African Agricultural Research Council - Animal 
Production Institute, approved animal use. The experimental treatments were three grounded AP silages, viz: control, EMS and Sil. The samples of the 3 silages were milled through a 2-mm screen and $6.5 \mathrm{~g}$ subsamples placed in polyester bags $(10 \times 20 \mathrm{~cm} ; 50 \mu \mathrm{m}$ pore size) (Ankom, Fairport NY, USA) to achieve 15 $\mathrm{mg} / \mathrm{cm}^{2}$ (ratio of sample size to surface area bag). For each silage treatment, bags were incubated simultaneously in the ventral rumen of each cow, in triplicate for $2,4,8,16,24$, or $48 \mathrm{~h}$. Two duplicate sets of each sample were not incubated in the rumen, but were washed in cold water as above to determine solubility at $0 \mathrm{~h}$. Immediately following incubation, bags were removed from the rumen and immersed in 20-L buckets containing cold $\left(4^{\circ} \mathrm{C}\right)$ water before washing in a washing machine until clean water was obtained and dried at $60{ }^{\circ} \mathrm{C}$ for $48 \mathrm{~h}$ in an oven. Dried bags were individually weighed, the content of each bag removed and stored into glass vial until analysis.

A $40 \mathrm{~g}$ representative sample of pre-ensiled AP mixture and that of silages were taken from each treatment to determine the fermentation characteristics. The $40 \mathrm{~g}$ silage sample (three samples/treatment) was mixed with $360 \mathrm{ml}$ of distilled water in a stomacher bag, homogenized for $4 \mathrm{~min}$ and $\mathrm{pH}$ was determined immediately with a pH meter (Thermo Orion Model 525, Thermo Fisher Scientific, Waltham, MA, USA). Each sample was then filtered through a Whatman No. 54 filter paper (G.I.C. Scientific, Midrand, Gauteng, South Africa). The extract was used for determination of water soluble carbohydrates (WSC), volatile fatty acids (VFA), lactic acid (LA) and ammonia-N. The WSC were determined by the phenol-sulphuric acid method of Dubois et al. (1956) and LA was determined by the modified colorimetric method of Pryce (1969). The VFA were determined with a Varian 3300 FID Detector gas chromatograph (Varian Associates, Inc., Palo Alto, CA, USA) by the procedure of Suzuki and Lund (1980).

The DM of pre-ensiled mixtures and that of silages was determined by drying the samples at $60{ }^{\circ} \mathrm{C}$ until a constant mass was achieved, and was corrected for loss of volatiles using the equation of Weissbach and Strubelt (2008). After drying, the samples were ground through a 1-mm screen (Wiley mill, Standard Model 3, Arthur $\mathrm{H}$. Thomas Co., Philadelphia, PA) for crude protein (CP), gross energy (GE), fibre (aNDF, $A D F$ and $A D L$ ) and ether extract (EE) analyses following standard procedures of AOAC (2003). The gross energy (GE) was determined with a bomb calorimeter (MC-1000 modular calorimeter, Energy Instrumentation, 135 Knoppieslaagte, Centurion, South Africa).

Dry matter disappearance and the effective degradability (ED) with time were calculated according to Ørskov and McDonald (1979) and Denham et al. (1989), respectively as:

$$
\begin{gathered}
D=a+b\left(1-e^{-c t}\right) \\
E D=a+b\left(\frac{b c}{c+k}\right) e^{-k t}
\end{gathered}
$$

Where: $\mathrm{D}$ and $\mathrm{ED}$ are the degradation and effective degradability after t hours of rumen incubation,

$\mathrm{a}$ is the water-soluble and rapidly degradable fraction,

$\mathrm{b}$ is the insoluble but degradable fraction, and

$\mathrm{c}$ is the degradation rate of fraction $\mathrm{b}$.

The nonlinear procedure of SAS (PROC NLIN, version 9.1, SAS Institute Inc. Cary, NC, USA) was used to fit the degradation data to the models and the model yielding the minimal sum of squares was retained as a better fit to the data set. Passage rate was calculated at $0.05 \mathrm{~h}-1$ from the equation developed by NRC (2001) for concentrates.

Data on effects of treatments on fermentation, chemical composition and aerobic stability of AP silage were analysed in a completely randomized design by ANOVA using Genstat (VSN International, Hemel Hempstead, UK). Differences among treatment means were compared with least significant difference (LSD) and significance was declared at the $0.05 \%$ probability level (Snedecor \& Cochran, 1980). Data was fitted to the model:

$$
Y_{i j}=\mu+t_{i}+\varepsilon_{i j}
$$

Where: $Y_{i j} j^{\text {th }}$ observation of the dependent variable,

$\mu$ is the overall mean,

$t_{i}$ is the effect of the $\mathrm{i}^{\text {th }}$ treatment, and

$\varepsilon_{i j}$ is random error.

The estimates of $a, b, c$, ED and the percentage of DM disappearance at different incubation times were analysed using randomized complete block design with SAS (PROC MIXED, version 9.1, SAS Institute Inc. Cary, NC, USA). The model was: 


$$
Y_{i j k}=\mu+f_{i}+c_{j}+e_{i j k}
$$

where: $Y_{i j k}$ is the $k^{\text {th }}$ observation of the dependent variable,

$\mu$ is the overall mean,

$f_{i}$ is the fixed effect of $i^{\text {th }}$ treatment,

$c_{j}$ is the random effect of $j^{\text {th }}$ cow, and

$e_{i j k}$ is random error.

\section{Results}

It is evident that the DM and WSC contents of AP before ensiling were quite low for efficient ensiling (Table 1). Mixing AP with dried GP increased the DM, WSC and the fibre fractions of the ensiled mixture.

Although the effects of treatments did not affect the final $\mathrm{pH}$ (Figure 1), AA and BA contents in the AP silage, the DM and LA levels of the control were $11 \mathrm{~g} \mathrm{DM} / \mathrm{kg}$ and $7 \mathrm{~g} \mathrm{LA} / \mathrm{kg}$ DM lower $(P<0.05)$ than those of the treated silages (Table 2). Microbial inoculation increased $(P<0.05)$ the population of $L A B$ in the silage, which subsequently resulted in an increased $(P<0.05)$ residual fermentation substrate and LA production compared to the control treatment. Inoculation reduced $(P<0.05)$ the fibre fractions and the fat content of the silage compared to the control treatment. The aerobic stability of AP silage was reduced $(P$ $<0.05$ ) with inoculation as indicated by increase in $\mathrm{pH}$, carbon dioxide production and the population of yeasts and moulds while reducing the number of hours the silage remained stable.

Table 1 Chemical composition of forages before ensiling $(n=3)$

\begin{tabular}{lccc}
\hline & \multicolumn{3}{c}{ Treatments } \\
\cline { 2 - 4 } Parameter & Avocado pulp & Dried grape pumice & Mixture \\
\hline $\mathrm{DM}, \mathrm{g} \mathrm{kg}^{-1}$ & $119 \pm 30$ & $953 \pm 5$ & $343 \pm 10$ \\
$\mathrm{WSC}, \mathrm{g} \mathrm{kg}^{-1} \mathrm{DM}$ & $61.6 \pm 1.7$ & $14.6 \pm 1.2$ & $90.6 \pm 1.8$ \\
$\mathrm{pH}$ & $4.57 \pm 0.06$ & $4.13 \pm 0.15$ & $5.63 \pm 0.06$ \\
$\mathrm{CP}, \mathrm{g} \mathrm{kg}^{-1} \mathrm{DM}$ & $77.9 \pm 1.6$ & $131.0 \pm 1.9$ & $97.2 \pm 0.4$ \\
$\mathrm{GE}, \mathrm{MJ} \mathrm{kg}^{-1} \mathrm{DM}$ & $19.7 \pm 0.3$ & $16.8 \pm 0.2$ & $19.5 \pm 0.1$ \\
$\mathrm{EE}, \mathrm{g} \mathrm{kg}^{-1} \mathrm{DM}$ & $118 \pm 1$ & $62.9 \pm 2$ & $141 \pm 2$ \\
$\mathrm{aNDF}, \mathrm{g} \mathrm{kg}^{-1} \mathrm{DM}$ & $439 \pm 2$ & $477 \pm 1$ & $469 \pm 2$ \\
$\mathrm{ADF}, \mathrm{g} \mathrm{kg}^{-1} \mathrm{DM}$ & $339 \pm 4$ & $290 \pm 1$ & $317 \pm 2$ \\
$\mathrm{ADL}, \mathrm{g} \mathrm{kg}^{-1} \mathrm{DM}$ & $147 \pm 1$ & $190 \pm 1$ & $146 \pm 1$
\end{tabular}

DM: dry matter; WSC: water-soluble carbohydrates; CP: crude protein; GE: gross energy; EE,: ether extract; aNDF: amylase treated neutral detergent fibre; ADF: acid detergent fibre; ADL: acid detergent lignin 


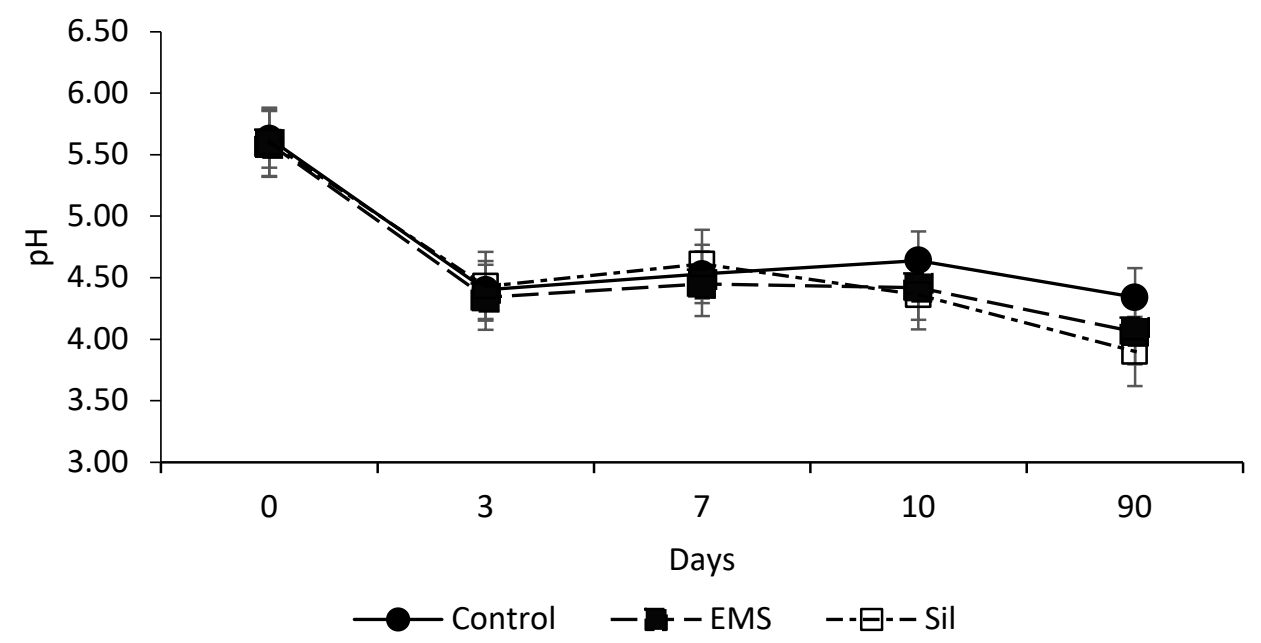

Figure 1 Effects of treatment on the $\mathrm{pH}$ reduction of avocado silage relative to days of ensiling

EMS: Emsilage inoculant; SIL: Sil-All 4x4 W.S. inoculant

Table 2 The effects of treatment on the fermentation characteristics, nutritive value and aerobic stability of ensiled avocado mixture $(n=3)$

\begin{tabular}{|c|c|c|c|c|c|}
\hline \multirow[b]{2}{*}{ Characteristic } & \multicolumn{3}{|c|}{ Treatments } & \multirow[b]{2}{*}{ SE } & \multirow[b]{2}{*}{$P$-value } \\
\hline & Control & EMS & SIL & & \\
\hline \multicolumn{6}{|c|}{ Fermentation characteristics } \\
\hline $\mathrm{DM}, \mathrm{g} \mathrm{kg}^{-1}$ & $332.9^{b}$ & $346.7^{\mathrm{a}}$ & $343.5^{\mathrm{a}}$ & 1.9 & 0.005 \\
\hline WSC, $\mathrm{g} \mathrm{kg}^{-1} \mathrm{DM}$ & $17.9^{\mathrm{C}}$ & $38.0^{\mathrm{b}}$ & $50.4^{\mathrm{a}}$ & 0.7 & 0.001 \\
\hline LAB $\log ^{10} \mathrm{CFU} \mathrm{kg}^{-1}$ & $1.73^{\mathrm{C}}$ & $7.63^{\mathrm{a}}$ & $3.33^{\mathrm{b}}$ & 0.15 & 0.001 \\
\hline $\mathrm{pH}$ & 4.3 & 4.1 & 3.9 & 0.1 & 0.079 \\
\hline $\mathrm{LA}, \mathrm{g} \mathrm{kg}^{-1} \mathrm{DM}$ & $40.7^{b}$ & $48.6^{a}$ & $46.6^{\mathrm{a}}$ & 0.6 & 0.001 \\
\hline$A A, \mathrm{~g} \mathrm{~kg}^{-1} \mathrm{DM}$ & 5.32 & 4.80 & 6.01 & 0.47 & 0.268 \\
\hline BA, $\mathrm{g} \mathrm{kg}^{-1} \mathrm{DM}$ & 0.70 & 0.67 & 1.00 & 0.29 & 0.668 \\
\hline \multicolumn{6}{|c|}{ Nutritive value } \\
\hline $\mathrm{CP}, \mathrm{g} \mathrm{kg}^{-1} \mathrm{DM}$ & 95.9 & 93.4 & 98.0 & 1.2 & 0.079 \\
\hline$E E, \mathrm{~g} \mathrm{~kg}^{-1} \mathrm{DM}$ & $135.4^{\mathrm{a}}$ & $127.8^{\mathrm{b}}$ & $102.5^{\mathrm{c}}$ & 0.4 & 0.001 \\
\hline aNDF, $\mathrm{g} \mathrm{kg}^{-1} \mathrm{DM}$ & $531.0^{\mathrm{a}}$ & $503.3^{b}$ & $497.6^{\mathrm{b}}$ & 4.2 & 0.003 \\
\hline$A D F, g ~ k g^{-1} D M$ & $359.1^{\mathrm{a}}$ & $335.8^{\mathrm{b}}$ & $334.3^{b}$ & 1.8 & 0.001 \\
\hline ADL, $\mathrm{g} \mathrm{kg}^{-1} \mathrm{DM}$ & $164.0^{\mathrm{a}}$ & $158.7^{\mathrm{ab}}$ & $155.7^{b}$ & 1.8 & 0.043 \\
\hline \multicolumn{6}{|c|}{ Aerobic stability $^{1}$} \\
\hline $\mathrm{DM}, \mathrm{g} \mathrm{kg}^{-1}$ & 338.6 & 337.1 & 330.3 & 3.5 & 0.282 \\
\hline $\mathrm{pH}$ & $5.4^{\mathrm{c}}$ & $5.9^{b}$ & $6.5^{\mathrm{a}}$ & 0.1 & 0.002 \\
\hline $\mathrm{CO}_{2}, \mathrm{~g} \mathrm{~kg}^{-1} \mathrm{DM}$ & $8.1^{\mathrm{c}}$ & $13.8^{\mathrm{b}}$ & $20.6^{a}$ & 0.5 & 0.001 \\
\hline Yeast \& moulds $\log ^{10} \mathrm{CFU} \mathrm{kg}{ }^{-1}$ & $7.57^{\mathrm{b}}$ & $7.10^{\mathrm{b}}$ & $8.87^{\mathrm{a}}$ & 0.16 & 0.001 \\
\hline Temperature changes (hrs) & $27^{\mathrm{b}}$ & $42^{a}$ & $39^{a}$ & 1 & 0.005 \\
\hline
\end{tabular}

${ }^{a-c}$ Means within a row with different superscripts differ $(P<0.05)$.

DM: dry matter; WSC: water-soluble carbohydrates; LAB: lactic acid bacteria; LA: lactic acid; AA: acetic acid; BA: butyric acid; CP: crude protein; EE: ether extract; aNDF: amylase treated neutral detergent fibre; ADF: acid detergent fibre; ADL: acid detergent lignin; $\mathrm{CO}_{2}$ : carbon dioxide; $\mathrm{CFU}$ : colony forming unit EMS: Emsilage inoculant; SIL: Sil-All 4x4 W.S. inoculant

${ }^{1}$ after 7 days of aerobic exposure. 
Dry matter degradability of the forages before ensiling is shown in Table 3 . The AP and its mixture had higher $(P<0.05)$ soluble fractions compared to that of the GP $(13 \%)$. However, the potential degradable fraction and the extent of degradation did not differ amongst the three forages. The degradation rate was higher $(P<0.05)$ in the GP compared to the other two forages.

Table 3 Dry matter degradability of forages at pre-ensiling $(n=3)$

\begin{tabular}{lcrrrr}
\hline & \multicolumn{2}{c}{ Forages } & & \\
\cline { 2 - 4 } & Mixture & Grape pumice & Avocado pulp & SE & $P$-value \\
\hline a & $29.8^{\mathrm{a}}$ & $13.3^{\mathrm{b}}$ & $32.1^{\mathrm{a}}$ & 1.66 & 0.004 \\
$\mathrm{~b}$ & 38.1 & 44.4 & 38.4 & 12.27 & 0.771 \\
$\mathrm{C}$ & $0.01^{\mathrm{b}}$ & $0.05^{\mathrm{a}}$ & $0.02^{\mathrm{b}}$ & 0.01 & 0.004 \\
PD & 67.9 & 62.7 & 70.5 & 11.83 & 0.894 \\
ED & 36.1 & 39.6 & 41.5 & 2.31 & 0.323 \\
\hline
\end{tabular}

${ }^{\mathrm{a}, \mathrm{b}}$ Means within a row with different superscripts differ $(P<0.05)$.

a: soluble fraction; $b$ : potentially degradable fraction; $c$ : degradation rate constant of the $b$ fraction; PD: extent of degradation $(a+b)$; ED: effective degradability (outflow rate $=0.05)$.

Results on the effect of treatments on DM degradation in AP silage are shown in Table 4. The EMS treatment had higher $(P<0.05)$ soluble fractions and lower degradation rate compared to the other treatments. The silage DM of the control and that of the SIL treatment disappeared more rapidly than that of EMS treatments, and approximately $80 \%$ of DM in the control and EMS disappeared within 24 hrs of incubation while only 65\% disappeared for the SIL treatment (Figure 2). Inoculation did not affect the extent of degradation of the AP silage. However, the effective degradation of the silage DM was improved $(P<0.05)$ with SIL inoculation compared to the other treatments.

Table 4 Dry matter degradation characteristics of avocado oil cake silage after $90 \mathrm{~d}$ of ensiling ( $n: 3)$

\begin{tabular}{|c|c|c|c|c|c|}
\hline & \multicolumn{3}{|c|}{ Treatments $^{1}$} & \multirow[b]{2}{*}{ SE } & \multirow[b]{2}{*}{$P$-value } \\
\hline & Control & EMS & SIL & & \\
\hline$a$ & $33.4^{\mathrm{b}}$ & $37.3^{a}$ & $34.4^{b}$ & 0.33 & 0.004 \\
\hline b & 34.0 & 36.7 & 34.9 & 3.12 & 0.838 \\
\hline c & $0.07^{b}$ & $0.03^{c}$ & $0.09^{a}$ & 0.01 & 0.001 \\
\hline PD & 67.9 & 73.9 & 69.3 & 3.06 & 0.358 \\
\hline ED & $57.2^{b}$ & $49.3^{c}$ & $62.1^{\mathrm{a}}$ & 0.97 & 0.003 \\
\hline
\end{tabular}

\footnotetext{
${ }^{a-c}$ Means within a row with different superscripts differ $(P<0.05)$.

a: soluble fraction; b: potentially degradable fraction; $c$ : degradation rate constant of the $b$ fraction; PD: extent of degradation $(a+b)$; ED: effective degradability (outflow rate $=0.05$ )

${ }^{1}$ EMS: Emsilage inoculant; SIL: Sil-All 4x4 W.S. inoculant
} 

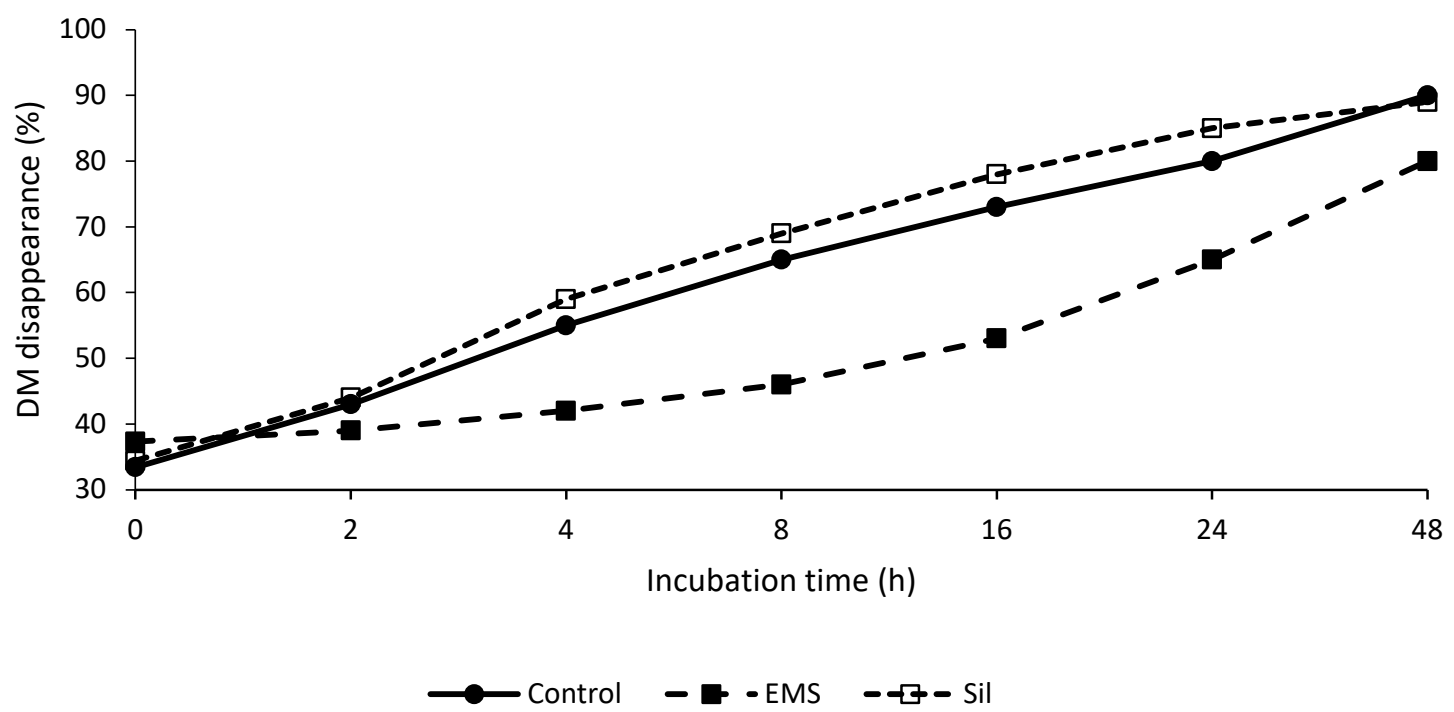

Figure 2 Avocado pulp silage dry matter disappearance over time

EMS: Emsilage inoculant; SIL: Sil-All 4x4 W.S. inoculant

\section{Discussion}

The DM content of forage at ensiling has a strong influence on the rate and extent of the resulting fermentation. When silage DM content is less than $250 \mathrm{~g} / \mathrm{kg}$, conditions for clostridial activity are favourable, resulting in high losses and silage of low nutritional value (Wilkinson, 2005). The results of the DM and WSC of the AP (Table 1) in the present study reflects low mean concentrations of DM (119 g DM/kg) and WSC (61.6 $\mathrm{g} \mathrm{WSC} / \mathrm{kg} \mathrm{DM})$, which would generally classify this material as likely to produce poor fermentation patterns. The DM content of AP was comparable to $186 \mathrm{~g} \mathrm{DM} / \mathrm{kg}$ of AP reported by Eliyahu et al. (2015). In a review by Henderson and McDonald (1984), they suggested that the use of inoculants to such forages might not improve silage quality due to the limitation of fermentable substrate. Consequently, we have mixed the AP with GP and added sugarcane molasses to improve both the DM and the fermentable substrate. This has resulted in a DM of $343 \mathrm{~g} \mathrm{DM} / \mathrm{kg}$ and $90.6 \mathrm{WSC} / \mathrm{kg} \mathrm{DM}$, sufficient for ensiling.

Higher DM values were observed for AP silage treated with LAB inoculants compared to the control (Table 2), which might be associated with maintaining of the homofermentative type of fermentation where the DM losses are lower. This is consistent with Ferreira et al. (2014) who reported an improved DM content of elephant grass silage treated with LAB inoculant compared to untreated silage. The crude protein content of a forage or feed is one of the important components to enhance animal performance, and low levels may negatively influence animal performance. According to van Soest (1994), feed resources that contain less than $70 \mathrm{~g} \mathrm{CP} / \mathrm{kg}$ DM do not support optimum rumen fermentation and may result in a depressed feed intake. The CP content of AP in the present study was $77.9 \mathrm{~g} \mathrm{CP} / \mathrm{kg} \mathrm{DM}$ (Table 1), higher than this threshold but lower than $147 \mathrm{~g} \mathrm{CP} / \mathrm{kg}$ DM and $156 \mathrm{~g} \mathrm{CP} / \mathrm{kg}$ DM reported by Eliyahu et al. (2015) and Skenjana et al. (2006) in AP, respectively. This difference might be related to the different processing methods used during oil production from avocados and differences in avocado cultivars used. Microbial inoculation to forages at ensiling has been reported to reduce proteolysis, hence improving the CP content of silage (Nkosi et al., 2009; Ferreira et al., 2014). Although the CP content of AP silage did not differ among the treatments, it was similar to other studies of maize silage (e.g. Nkosi et al., 2009). Thus, CP supplementation will be required when feeding this silage to high producing animals.

Silage $\mathrm{pH}$ is one of the main criteria reflecting the extent of fermentation and quality of ensiled forages. Unexpected, microbial inoculation to AP at ensiling did not affect terminal $\mathrm{pH}$ in this study. Working on capim-marandu pastures (Brachiara brizanthia cv Marandu), Bergamaschine et al. (2006) reported no difference in the $\mathrm{pH}$ in the control treatment compared with inoculated silages, which is consistent with the results of the present study. However, there was a consistent decrease in the $\mathrm{pH}$ of the silages across days (Figure 1), indications of proper fermentation. After $90 \mathrm{~d}$, the $\mathrm{pH}$ of the silages was reduced to 4.1 or less, characteristics of a well-preserved silage (McDonald et al., 2010). Eliyahu et al. (2015) recorded a final pH of 5.12 in AP silage produced without additives, which is higher than the $\mathrm{pH}$ values recorded in the present study. 
Water-soluble carbohydrates are regarded as essential substrates for growth of LAB for proper fermentation (McDonald et al., 2010), and low levels may restrict LAB growth. Lunden-Pettersson and Lindgren (1990) recommended an amount of $60-70 \mathrm{~g} \mathrm{WSC} / \mathrm{kg}$ DM for achieving well-preserved silage. According to Addah et al. (2011), the initial WSC concentration in forages varies widely with genotype, maturity at harvest and climatic conditions such as crop heat units and frost. Eliyahu et al. (2015) reported $15.3 \mathrm{WSC} / \mathrm{kg} \mathrm{DM}$ in AP at pre-ensiling, which is lower than $61.6 \mathrm{~g} \mathrm{WSC} / \mathrm{kg} \mathrm{DM}$ reported in the present study (Table 1). After $90 \mathrm{~d}$ of fermentation, higher $(P<0.05)$ residual WSC was observed for the microbial inoculant treatments compared to the control (Table 2). This might be attributed to the higher $(P<0.05)$ NDF degradation in AP silage treated with microbial inoculants in relation to the control treatment, making more sugars available to stimulate fermentation in the AP silage. Higher residual WSC in silage may be beneficial to ruminants since it supplies energy to animals (Tava et al., 1995; McDonald et al., 2010), but may serve as substrate for aerobic microbes during feeding of silage to ruminants (Muck et al., 2018).

Lactic acid (LA) is the strongest of all silage acids and its presence will reduce the pH more effectively than VFAs. Achieving an increase in the content of LA is the most reliable indicator for the success of an inoculant in improving silage quality. The LA content in AP silage was increased with LAB inoculation compared to control treatment, consistent with other reports (Mari et al., 2009; Nkosi et al., 2009). In contrast, other studies reported a lack of response on the influence of LAB inoculation to LA content of silage in relation to untreated silage (McAllister et al., 1995). The LAB treated AP silage had higher LAB population compared to the control (Table 2). This increase in LAB population in the inoculant treatments helped to reduce $\mathrm{pH}$ more rapidly. Degradation of the fibre fractions of the inoculated AP silage subsequently increased its residual WSC which may be attributed to the enzymes present in the inoculants. This finding is consistent with Keady and Steen (1994) but contrasting other researchers (Kung et al., 1987; Rooke et al., 1988) who reported no reduction in fibre fraction of silage with LAB inoculation.

The aerobic deterioration of silage may increase the risk of proliferation of potential pathogenic or undesirable micro-organisms thus affecting the performance of animals fed the silage. A higher $\mathrm{CO}_{2}$ production in silage indicates the activity of yeasts and moulds, which cause a rise in temperature and deteriorate the quality of silage (Woolford, 1990; Ashbell et al., 1991). The increase concentration of acetic acid (AA) has been reported in many studies (e.g. Mari et al., 2009; Nkosi et al., 2009) as a solution to stabilize silage when exposed to air. This is achieved by inoculation of forages with LAB inoculants that promotes a hetero-fermentative type pathway (mostly those that contain Lactobacillus buchneri strains). However, LAB inoculation did not affect the AA content of the AP silage. The aerobic stability of the LAB treated AP silage was reduced $(P<0.05)$ based on the higher $\mathrm{CO}_{2}$ production and reduced number of hours it remained stable, compared to the control (Table 3). This might be attributed to the higher contents of residual sugar and LA in these treatments, which might have served as energy sources for the growth of yeasts and moulds (Muck et al., 2018). This concurs with previous reports whereby the aerobic stability of forage soybean (Nkosi et al., 2016) and forage Hedychium gardnerianum (Moselhy et al., 2015) was impaired with homofermentative LAB inoculation. In contrast, Uriarte-Achundia et al. (2002) reported improved aerobic stability in maize silage treated with $L A B$ inoculant.

The soluble fraction and the potentially degradable fractions of the AP in the present study concurs that of Skenjana et al. (2006) who reported 32\% soluble fraction and 35\% potential degradable fraction in AP. The difference in the chemical composition of the three products at pre-ensiling affected the soluble and potentially degradable fraction of DM (Table 3). The two fractions of the DM did not differ between the mixture and AP, averaging 30.9 and $0.015 \%$, respectively, but were respectively lower and higher $(P<0.05)$ than GP. The lower soluble DM fraction of GP can be attributed to its reported high lignified cell wall (GuerraRivas et al., 2017) (Table 1). The ED at both passage rates (ED1 and ED2) were relatively constant in all forages with an average of 46.9 and $39.1 \%$, respectively.

The use of $L A B$ inoculants during ensiling is expected to enhance silage use and consequently favour the microbial population in the rumen, thus influencing silage degradation. Although it is generally recognised that $L A B$ inoculation markedly enhances silage fermentation and increases DM recovery, but their reported effects on silage DM degradability has been inconsistent. Some studies have shown that LAB inoculation to forages at ensiling could improve ruminal degradability of silage (Reyes-Guterrez et al., 2015; Li et al., 2017). In contrast, there are studies that have shown that LAB did not affect ruminal degradation of silage (Keady \& Steen, 1994; Filya, 2003). SIL inoculation improved the degradation rate of the insoluble DM fraction of AP silage and consequently improved its effective degradability, while EMS application improved the soluble DM fraction degradability.

According to Thomas et al. (2013), silages exhibiting a higher soluble fraction have a reduced potentially degradable fraction of DM. The soluble fraction of DM was higher in the EMS treated AP silage, which is likely to be attributed to the higher WSC content in the silage. Treating AP silage with SIL increased the undegradable fraction of DM while it was reduced with EMS treatment. Inoculation of AP with SIL at 
ensiling increased the degradation rate of the potentially degradable DM fraction, which is reported to play a dominant role in the degradation characteristics (Woods et al., 2003) resulting in an increase in ED (Table 4). The well-known effects of facultative hetero-fermenters are the increase in lactic acid, decrease in $\mathrm{pH}$ value and ammonia, but do not effectively degrade plant cell walls (McDonald et al., 2010). However, microbial inoculation of AP at ensiling resulted in reduced fibre fractions (aNDF, ADF, and ADL) of the silage which might be attributed to the different microbial strains that are present in the inoculants. The treatment of AP silage with $L A B$ inoculants did not affect the potentially degradable DM of silage, which is inconsistent with Thomas et al. (2013) who reported a decrease in the potentially degradable DM with LAB inoculation of sorghum at ensiling.

In spite of the higher soluble fraction in the EMS treated silage, the insoluble potentially degradable "b" fraction of DM did not differ amongst the treatment, which contradicts Ferreira et al. (2014) who reported a reduced insoluble potential degradable "b" fraction in elephant grass silage treated with LAB inoculant. The higher soluble DM degradability in the AP silage treated with EMS inoculant was probably due to reduced moisture content of the silage (Table 2), which favoured the growth of LAB in detriment to enterobacteria. It is known that higher ADF content decrease feed digestibility due to the presence of lignin (van Soest, 1994), and that high fat content lead to a physical covering of feed particles, limiting the attack by microorganisms (Palmquist \& Mattos, 2006). The AP silage treated with LAB inoculants had lower contents of fibre fractions and fat, which might be the reason for improved DM degradation of the silage compared to the untreated silage. This enhanced rumen degradation rates of DM indicate that the LAB inoculants (EMS and Sil) may have increased the available energy to rumen microbes (Thomas- Moen et al., 2014). However, the nonresponse of $L A B$ inoculation to the undegradable DM fractions of the AP silage contradicts the findings of Thomas-Moen et al. (2014) who reported reduced undegradable fractions with LAB inoculation to either wheat or oat forages. This suggests that $L A B$ could differently affect ruminal degradability of different roughages. Although LAB inoculation to whole crop barley resulted in reduced silage $\mathrm{pH}$ and increased LA content, this did not result in an improved DM degradability of the silage (Hristov \& McAllister, 2002). In contrast, $\mathrm{LAB}$ inoculation to AP at ensiling improved both the fermentation of silage and ruminal DM degradation.

It is worth to note that the mean values obtained in the AP silage soluble DM in fraction "a" (Table 4) are lower than $48 \%$ soluble DM fraction reported in maize silage by von Keyserlingk et al. (1996). The differences in soluble DM may be attributed to differences in non-structural carbohydrate content of the forage since most non-structural carbohydrates in maize are water-soluble and thus fermented during the ensiling process. However, these researchers reported a degradable DM fraction "b" of $38 \%$, which is comparable to that of AP silage in the present study. Working on silage produced from various sorghum cultivars, Thomas et al. (2013) recorded $32 \%$ soluble fraction (a) and $38 \%$ potentially degradable fraction (b) of DM, which is comparable to the AP silage in the present study.

\section{Conclusions}

Microbial inoculation to AP at ensiling improved the ensiling process of the AP silage but reduced silage aerobic stability as indicated by high population of yeasts and moulds in the silage. However, inoculation with SIL improved both the effective DM degradation and the degradation rate of the insoluble DM fraction of AP silage, while EMS inoculation improved the soluble DM fraction degradability. The making of silage from AP could contribute to better use of this resource as feed for ruminants. Further work to test AP silage on ruminant growth performance should be pursued.

\section{Acknowledgements}

The authors wish to thank Ms Cynthia Ngwane (ARC-Biometrics) for assistance in the statistical analyses of the data. The National Research Foundation in South Africa is also acknowledged for funding this research.

\section{Authors' Contributions}

BDN and RM were in charge of project design and writing of the manuscript. BDN, MCM, TL, MDM, RST, JAVN and IMMM were in charge of project implementation. All co-authors participated in results, statistics and interpretation of the study. The final manuscript was read and approved by all authors.

\section{Conflict of Interest Declaration}

We wish to confirm that there are no known conflicts of interest associated with the publication of this manuscript and there has been no significant financial support for this work that could have influenced its outcome.

\section{References}

Addah, W., Baah, J., Groenewegen, P., Okine, E.K. \& McAllister, T.A., 2011. Comparison of the fermentation characteristics, aerobic stability and nutritive value of barley and corn silages ensiled with or without a mixed bacterial inoculant. Can. J. Anim. Sci. 91, 133-146. 
AOAC, 2003. Official Methods of Analysis of the Association of Official's Analytical Chemists, $17^{\text {th }}$ edn. Association of Official Analytical Chemists, Arlington, Virginia.

Ashbell, G., Weinberg, Z.G., Azriel, A., Hen, Y. \& Horev, B., 1991. A simple system to study the aerobic deterioration of silages. Can. Agric. Eng. 33, 391-393.

Bergamaschine, A.F., Passipiéri, M. \& Veriano Filho W.V., 2006. Qualidade e valor nutritivo de silagens de capimmarandu (B. brizantha cv. Marandu) produzidas com aditivos ou forragem emurchecida. Revta Bras. Zootec. 35, 454-1462.

De Evan, T., Vintimilla, A., Marcos, C.N., José Ranilla, M. \& Carro, M.D., 2019. Evaluation of Brassica vegetables as potential feed for ruminants. Anim. 9, 588-601.

Denham, S.C., Morantes, G.A., Bates, D.B. \& Moore, J.E., 1989. Comparison of two models used to estimate in situ nitrogen disappearance. J. Dairy Sci. 72, 708-714.

Dos Santos Belem, C., de Souza, A.M., de Lima, P.R., de Carvhalho, F.A.L., Queiroz, M.A.A. \& da Costa, M.M., 2016. Digestibility, fermentation and microbiological characteristics of Calotropis procera silage with different quantities of grape pomace. Ceincia e Agrotecnol. http://dx.doi.org/10.1590/1413-70542016406020916.

Dubois, M., Gilles, K.A., Hamilton, J.K., Rebes, P.A. \& Smith, F., 1956. Colorimetric method for determination of sugars and related substances. Anal. Chem. 28, 350-356.

Eliyahu, D., Yosef, E., Weinberg, Z.G., Hen, Y., Nikbachat, M., Solomon, R., Mabjeesh, S.J. \& Miron, J., 2015. Composition, preservation and digestibility by sheep of wet by-products from the food industry. Anim. Feed Sci. Technol. 207, 1-9.

Filya, I., 2003. The Effect of Lactobacillus buchneri and Lactobacillus plantarum on the fermentation, aerobic stability and ruminal degradability of low dry matter corn and sorghum silages. J. Dairy Sci., 86, 3575-3581.

Federation of Animal Science Societies (FASS), 2010. Guide for the Care and Use of Agricultural Animals Used in Agricultural Research and Teaching. 3rd Edition. Federation of Animal Science Societies, 2441 Village Green Place, Champaign, IL, 61822.

Ferreira, D.J., Zanine, A.M., Lana, R.P., Ribeiro, M.D., Alves, G.R. \& Mantovani, H.C., 2014. Chemical composition and nutrient degradability in elephant grass silage inoculated with Streptococcus bovis isolated from the rumen. Anais da Academia Brasil. de Ciencias, 86, 465-473.

Guerra-Rivas C., Gallardo, B., Mantecón, Á.R., del Álamo-Sanzaa, M. \& Mansoa. T., 2017. Evaluation of grape pomace from red wine by-product as feed for sheep. J. Sci. Food Agric. 97, 1885-1893.

Henderson, A.R. \& McDonald, P., 1984. The effect of a range of commercial inoculants on the biological changes during the ensilage of grass in laboratory studies. Res. Developm. Agric., 1, 171-176.

Hristov, A.N. \& McAllister, T.A., 2002. Effect of inoculants on whole crop barley silage fermentation and dry matter disappearance in situ. J. Anim. Sci. 80, 510-516.

International Dairy Federation (IDF), 2004. International Standard 94B: Milk and milk products - enumeration of yeasts and moulds. Colony count technique at $25^{\circ} \mathrm{C}$. International Dairy Federation, Brussels, Belgium.

Keady, T.W. \& Steen, R.W.J., 1994. The effects of treating low dry matter grass with a bacterial inoculant on intake and performance of beef cattle and studies on its mode of action. Grass Forage Sci. 49, 438-446.

Kung Jr., L., Satter, L.D., Jones, B.A., Genin, K.W., Sudoma, A.L., Enders, Jr. G.L. \& Kim, H.S., 1987. Microbial inoculation of low moisture alfafa silage. J. Dairy Sci. 70, 2069-2077.

Li, M., Zhou, H., Zi., X. \& Cai, Y., 2017. Silage fermentation and ruminal degradation of stylo prepared with lactic acid bacteria and cellulose. Anim. Sci. J., 88, 1531-1537.

Lunden-Pettersson, K. \& Lindgren, S., 1990. The influence of carbohydrate fraction and additives on silage quality. Grass Forage Sci. 45, 223-233.

Mari, L.J., Schmidt, R.J., Nussio, L.G., Hallada, C.M. \& Kung, Jr. L., 2009. An evaluation of the effectiveness of Lactobacillus buchneri 40788 to alter fermentation and improve the aerobic stability of corn silage in farm silos. J. Dairy Sci. 92, 1174-1176.

McAllister, T.A., Selinger, L.B., McMahon, L.R., Bae, H.D., Lysyk, T.J., Oosting, S.J. \& Cheng, K-J., 1995. Intake, digestibility and aerobic stability of barley silage inoculated with mixtures of Lactobacillus plantarum and Enterococcus faecium. Can. J. Anim. Sci. 75, 425-432.

McDonald, P., Edwards, R.A., Greenhalgh, J.F.D., Morgan, C.A., Sinclair, L.A. \& Wilkinson, R.G., 2010. Animal Nutrition. $7^{\text {th }}$ Edition. Pearson, Prentice Hall.

Moselhy, M.A., Borba, J.P. \& Borba, A.E.S., 2015. Improving the nutritive value, in vitro digestibility and aerobic stability of Hedychium gardnerianu silage through application of additives at ensiling time. Anim. Feed Sci. Technol. 206, 8-18.

Muck, R.E., 2010. Silage additives and management issues. Proceedings of Idaho Alfalfa Forage Conference, Best Western Burley Inn, Burley, Idaho, USA. 16-17 February, pp. 49-55.

Muck, R.E., Nadeau, E.M.G., McAllister, T.A., Contreras-Govea, F.E., Santos, M.C. \& Kung Jr., L., 2018. Silage review: Recent advances and future uses of silage additives. J. Dairy Sci. 101, 3980-4000.

Nkosi, B.D., Meeske, R., Palic, D., Langa, T., Leeuw, K-J. \& Groenewald, I.B., 2009. Effects of ensiling whole crop maize with bacterial inoculants on the fermentation, aerobic stability, and growth performance of lambs. Anim. Feed Sci. Technol. 154, 193-203.

Nkosi, B.D., Meeske, R., Langa, T., Motiang, M.D., Modiba, S., Mkhize, N.R. \& Groenewald, I.B., 2016. Effects of ensiling forage soybean (Glycine $\max$ (L.) Merr.) with or without bacterial inoculants on the fermentation characteristics, aerobic stability and nutrient digestion of the silage by Damara rams. Small Rum. Res. 134, 9096. 
Nkosi, B.D., Thomas, R.S., Langa, T., Seshoka, M.M., Meeske, R. \& Van Niekerk, J., 2018. The aerobic stability of avocado (Persia Americana) pulp silage treated with microbial additives. Proceedings of the XVIII International Silage Conference, 24-26 July, Bonn, Germany, pp 330-331.

National Research Council (NRC), 2001. Nutrient requirements of dairy cattle. $7^{\text {th }}$ Edition Washington D.C, National Academies Press, pp. 1-347.

Ørskov, E. R. \& McDonald, I., 1979. The estimation of protein degradability in the rumen from incubation measurements weighted according to rate of passage. J. Agric. Sci 92, 499-503.

Palmquist, D.L. \& Mattos, W.R.S., 2006. Lipid metabolism. In: Berchielli, T.T., Pires, A.V., Oliveira, S.G. (eds.) Nutrition of Ruminants. Jaboticabal: FUNEP, pp. 287 - 310.

Pryce, J.D., 1969. Modification of the Barker \& Summerson method for the determination of lactic acid. Analyst 94,115 1152.

Reyes-Guitierrez, J.A., Montanez-Valdez, O.D., Rodriguez-Macias, R., Ruiz-Lopez, M., Salcedo-Perez, E. \& Guerramedina, C.E., 2015. Effect of a bacterial inoculum and additive on dry matter in situ degradability of sugarcane silage. J. Integrat. Agric., 14, 497-502.

Rooke, J.A., Maya, F.M., Amold, J.A. \& Armstrong, D.G., 1988. The chemical composition and nutritive value of grass silages prepared with no additive or with the application of additives containing either Lactobacillus plantarum or formic acid. Grass Forage Sci. 43, 87-102.

Rowghani, E., Zamiri, M.J. \& Seradj, A.R., 2008. The chemical composition, rumen degradability, in vitro gas production, energy content and digestibility of olive cake ensiled with additives. Iranian J. Vet. Res. 9, 213-221.

SAAGA, 2019. Overview of the South African Avocado Industry. www.avocado.co.za

Skenjana, A., van Ryssen, J.B.J. \& van Niekerk, W.A., 2006. In vitro digestibility and in situ degradability of avocado meal and macadamia waste products in sheep. S. Afr. J. Anim. Sci., 36, 78-81.

Snedecor, G.W. \& Cochran, W. G., 1980. Statistical methods. $7^{\text {th }}$ Edition, lowa State University Press. Ames, Iowa, USA.

Suzuki, M. \& Lund, C.W., 1980. Improved gas liquid chromatography for simultaneous determination of volatile fatty acids and lactic acid in silage. J. Agric. Food Chem. 28, 1040-1041.

Tava, A., Berardo, N., Cunico, C., Romani, M. \& Odoardi, M., 1995. Cultivar differences and seasonal changes of primary metabolites and flavour constituents in tall fescue in relation to palatability. J. Agric. Food Chem. 43, 98101.

Thomas, M.E., Foster, J.L., McCuistion, K.C., Redmon, L.A. \& Jessup, R.W., 2013. Nutritive value, fermentation characteristics, and in situ disappearance kinetics of sorghum silage treated with inoculants. J. Dairy Sci. 96, 7120-7131.

Thomas-Moen, M.E., Foster, J.L., McCuistion, K.C., Duncan, R.W., Redmon, L.A., Franks, A.M., Jessup, R.W. \& Olson, V., 2014. Inoculants to enhance the ruminal degradation of small-grain forage. Forage and Grazinglands, 12, 1-7.

Uriarte-Archunda, M.E., Bolsen, K.K. \& Brent, B.E., 2002. A study of the chemical and microbial changes in whole plant corn silage during exposure to air: effects of a biological additive and sealing technique. Kansas Agricultural Experimental Station Research Reports, vol. 0, 151-153.

Van Soest, P.J., 1994. Chapter 21: Intake. In: Nutritional ecology of the ruminant. $2^{\text {nd }}$ Ed., Cornell University Press, Ithaca, NY. pp. 337-353.

Von Keyserlingk, M.A.G., Swift, M.L., Puchala, R. \& Shelford, J.A., 1996. Degradability characteristics of dry matter and crude protein of forages in ruminants. Anim. Feed Sci. Technol. 57, 291-311.

Weissbach, F.E. \& Strubelt, C., 2008. Correcting the dry matter content of maize silages as a substrate for biogas production. 63 Landtechnik 2, 82-83.

Wilkinson, J.M., 2005. In: Silage (J.M. Wilkinson ed.). Part 6: Assessing silage quality. Chapter 19: Analysis and clinical assessment of silage. Chalcombe Publications, UK, pp. 198-208.

Woods, V.B., O'Mara, F.P. \& Moloney, A.P., 2003. The nutritive value of concentrate feedstuffs for ruminant animals. Part I: in situ ruminal degradability of dry matter and organic matter. Anim. Feed Sci. Technol. 110, 111-130.

Woolford, M.K., 1990. The detrimental effects of air on silage. J. Appl. Bacteriol. 68, 101-16. 